NBER WORKING PAPER SERIES

\title{
DETREBLING VERSUS DECOUPLING \\ ANTITRUST DAMAGES: \\ LESSONS FROM THE THEORY \\ OF ENFORCEMENT
}

A. Mitchell Polinsky

Working Paper No. 1846

\section{NATIONAL BUREAU OF ECONOMIC RESEARCH \\ 1050 Massachusetts Avenue \\ Cambridge, MA 02138 \\ February 1986}

Any opinions expressed are those of the author and not those of the National Bureau of Economic Research. 
NBER Working Paper \#1846

February 1986

Detrebling Versus Decoupling Antitrust Damages:

Lessons from the Theory of Enforcement

$\underline{\text { ABSTRACT }}$

This comment compares two alternative systems of private antitrust enforcement. In one (referred to as the "damage multiplier approach"), the plaintiff receives what the defendant pays; in the other (the "decoupling approach"), this constraint is not imposed. Reducing treble damages to single damages ("detrebling") would be an example of the first approach. Making the defendant pay treble damages while only giving the plaintiff single damages would be an example of the second approach. It is shown, using the principles of the the economic theory of enforcement, that the decoupling approach is preferable to the damage multiplier approach, and that the optimal system of decoupling could award the plaintiff more or less than what the defendant pays. Several additional issues are raised that need to be considered before decoupling can be recommended in practice.

A. Mitchell Polinsky Stanford Law School Stanford University Stanford, CA 94305 
One of the most talked about ideas in antitrust policy during the past several years is the notion of "detrebling" private antitrust damages. [1] This concept has several variations. Sometimes it refers to a mandatory reduction of treble damages to single damages for certain types of private antitrust actions (e.g., suits against joint research ventures), and other times it refers to a discretionary reduction of the damage multiplier on a case by case basis. For purposes of this comment, the critical feature of all of the detrebling proposals is that the plaintiff receives what the defendant pays. [2]

In sharp contrast to the attention given to detrebling is the almost complete absence of consideration given to the concept of "decoupling" antitrust damages. Decoupling refers to a system of liability in which the plaintiff receives something different than what the defendant pays. For example, the defendant might pay treble damages, with the plaintiff only receiving single damages (the difference being collected by the government). To my knowledge, the concept of decoupling antitrust damages was first proposed by Warren schwartz in an article in the Georgetown Law Journal in 1980, and then was completely ignored until it received brief mention in the paper by steven salop and Lawrence White prepared for this conference. [3]

The principal message of this comment is that the emphasis in antitrust policy discussions on detrebling--to the virtual exclusion of decoupling--is misplaced. I will argue, using the principles of the economic theory of enforcement, that there is a stronger case in favor of decoupling. I will also show, contrary 
to the presumption of Schwartz and of salop and White, that the optimal system of decoupling may require that the plaintiff receive more, rather than less, than what the defendant pays.

In the first part of the comment, the economic theory of enforcement is briefly reviewed. Then, in the second part, the lessons of the theory for the choice between detrebling and decoupling, and for the optimal design of a decoupling system, are discussed. In the final part of the comment, some remaining questions that need to be addressed before decoupling can be recommended in practice are mentioned.

\section{The Economic Theory of Enforcement}

The modern economic theory of enforcement began with a seminal paper by Gary Becker on crime and punishment. [4] Becker's theory, which assumes that the government does the enforcing, is easily explained. (In summarizing Becker's reasoning, I will refer to firms, although the same logic can be applied to individuals.) suppose firms obtain some gain from engaging in an activity that imposes costs on others. Examples of such activities include polluting the air, evading taxes, and attempting to monopolize an industry. If it were costless for the public enforcement authority to catch or observe firms when they engage in a harm-creating activity, presumably every firm would be caught and fined an amount equal to the external cost of the activity. Firms would then engage in the activity only if their private benefits exceed the external cost. And, from society's perspective, such behavior would be efficient. 
However, in most situations it is difficult or costly for the enforcement authority to catch firms that impose external costs. If, as a result, firms are not caught with certainty, they would engage in the harm-creating activity too often unless they are made to pay more than the harm caused when they are caught. Becker observed that the fine could be raised to a level such that, as before, firms would engage in the activity only if their private gains exceed the external cost. Since this outcome can be achieved for any given probability of catching firms and since it is costlier to catch a larger fraction of those engaging in the activity, Becker argued that the enforcement authority should set the probability very low and the fine correspondingly high.[5] This low probability/high fine combination characterizes the optimal system of public enforcement.

In a subsequent paper, Becker and George stigler suggested that a system of competitive private enforcement--in which the first individual or firm to discover and report the violation would receive the fine--could duplicate the outcome under optimal public enforcement. [6] This suggestion was quickly challenged by William Landes and Richard Posner.[7] Landes and Posner claimed that private enforcement would lead to too much enforcement relative to optimal public enforcement. Their intuitive explanation was based on the following observations. Under public enforcement, if detection were certain, the fine should be set equal to the external damage caused by the activity. By raising the fine and lowering the probability of detection, the same level of deterrence can be achieved at less cost. Under 
private enforcement, however, they pointed out that raising the fine would lead to a higher probability of detection since selfinterested private enforcers would be induced to invest more in enforcement. From this observation they concluded that a private system of enforcement would lead to "overenforcement."

In a paper following this exchange, I showed that Becker and stigler's hypothesis (that private enforcement could duplicate the public enforcement outcome) might be wrong for a different reason than that identified by Landes and Posner. [8] The main point of my paper was that private enforcement would lead in a wide range of circumstances to too little enforcement relative to optimal public enforcement. This result, which tends to occur when the external damage from the violation is large, can be explained as follows.

Under private enforcement, individuals or firms are willing to invest in enforcement only if they at least break even--that is, only if their fine revenue is at least as great as their enforcement costs. Under public enforcement, however, the optimal probability/fine combination may result in fine revenue which is less than enforcement costs. This is particularly likely to occur when the damage from the violation is large since it is then optimal to deter most, if not all, potential violators. Because the fine that can be imposed is limited (by the net worth of the potential violators), optimal public enforcement may require a high probability of detection and correspondingly large enforcement costs. But if most potential violators are deterred and the fine that can be obtained from 
those who are not is limited, the fine revenue collected by the public enforcement authority may well be less than the cost of enforcement. If so, private enforcers would not be willing to invest enough in enforcement to achieve the same level of deterrence as under public enforcement since they would not be able to break even. In other words, a private system of enforcement could lead to "underenforcement."

This summarizes the principal results in the economic theory of enforcement that are relevant to the present discussion.

\section{Lessons from the Theory}

There are two lessons that I wish to draw from the theory of enforcement, one concerning the choice between detrebling and decoupling, and the other relating to the optimal design of a decoupling system.

\section{Detrebling versus Decoupling}

One of the principal conclusions of the theory was that if private enforcers receive the fine paid by the injurer, it is generally impossible to achieve the optimal combination of the probability of detection and the fine. If the same fine is used as under optimal public enforcement, the resulting probability of detection (generated by the self-interested choices of private enforcers) may be too high or too low. In other words, if the enforcing is done privately, there may be too much enforcement or too little enforcement. The same conclusion applies to private damage actions in antitrust law since, under the current system, 
the plaintiff generally receives what the defendant pays. [9]

Advocates of detrebling presumably believe that awarding successful plaintiffs three times their damages induces them and their lawyers to invest too much in the detection and prosecution of antitrust violations. The only way to reduce enforcement under the present system is to reduce the damage multiplier. [10] However, as the discussion of the theory of enforcement makes clear, this response may not be the cheapest way to attain the desired level of deterrence. It may be socially preferable to raise, not lower, the amount paid by the defendant, while at the same time reducing the incentives for plaintiffs and their lawyers to invest in enforcement. If antitrust damages are decoupled, the lower level of deterrence that is desired can be achieved more cheaply by awarding the plaintiff less than what the defendant pays.

It should be stressed, however, that the advantage of decoupling over detrebling does not depend on whether it is desirable to reduce the level of deterrence from that currently generated by treble damages. The reasoning behind this conclusion is essentially the same as that used in the previous paragraph--specifically, that the decoupling approach can attain the same level of deterrence as any damage multiplier, but with a lower probability of detection, and therefore with lower enforcement costs. The details of the argument follow.

First select the best possible damage multiplier in a system in which the plaintiff receives what the defendant pays. This multiplier could be less than or greater than three. Whatever 
the multiplier is, it will generate some probability of detection as a result of the investment incentives of private enforcers. Now consider a system of decoupled damages. Under this system, raise the amount paid by the defendant from the level determined by the best damage multiplier.[II] If the plaintiff still were to receive the same amount as under the damage multiplier approach, the level of deterrence would be higher in the decoupled system because the probability of detection would be the same but the defendant would be paying more. Therefore, without changing what the defendant pays (from the now higher level), reduce the amount awarded to the plaintiff until the resulting probability of detection falls to a level such that the defendant is deterred to the same degree under both systems.

It is now easy to see why the decoupling approach is superior to the damage multiplier approach. Each approach can achieve the desired level of deterrence of antitrust violations. But the decoupling approach can attain this level of deterrence with a lower probability of detection, and therefore with lower enforcement costs. Thus, regardless of whether it is desirable to lower, raise, or leave unchanged the present damage multiplier of three, the decoupling approach is preferable to the damage multiplier approach.

\section{Optimal Decoupling}

Because of the focus on reducing private antitrust enforcement by detrebling antitrust damages, it is not surprising that the few individuals who have considered decoupling have 
taken for granted that the optimal system of decoupling would award the plaintiff less than what the defendant pays. This presumption would be correct if private enforcement is excessive under the damage multiplier approach, since it would then be desirable to discourage plaintiffs and their lawyers from investing too much in detection and prosecution. [12]

However, as noted earlier, private enforcement may lead to underenforcement rather than overenforcement. If private enforcement is inadequate, then the optimal system of decoupling would require that the plaintiff receive more than what the defendant pays (with the subsidy presumably coming from the government). For reasons explained earlier, this outcome is most likely to occur when the damage from the violation is large. Thus, the optimal system of decoupling could award the plaintiff more or less than what the defendant pays.

The implications of this conclusion for antitrust policy are straightforward. In those areas of antitrust law in which it is thought that overenforcement currently is a problem--for example, with respect to joint research ventures--the plaintiff could be given less than what the defendant pays. While in areas in which underenforcement might otherwise occur--for example, with respect to horizontal price fixing--the plaintiff could be awarded more than what the defendant pays.

It should be pointed out, in passing, that the conclusion that the optimal system of decoupling could award the plaintiff more than what the defendant pays is not inconsistent with the argument used to show that decoupling is superior to detrebling. 
The earlier argument demonstrated that there always exists some system of decoupling (one in which the plaintiff receives less than what the defendant pays) that is preferable to the best damage multiplier. It did not purport to derive the best system of decoupling, as is done here.

\section{Concluding Remarks}

The concept of decoupling is not an abstract curiosity derived from the economic theory of enforcement. There are several instances in which damages are already decoupled, although not always for the reasons suggested in this comment. For example, given current tax laws, antitrust damages are in effect decoupled in all private antitrust actions that follow successful criminal prosecutions by the government. In these cases, all of the plaintiff's award is treated as taxable income, while only one-third of the defendant's payment can be deducted. Thus, with the tax consequences taken into account, the plaintiff receives less than what the defendant pays (and the difference goes to the government). Although the tax treatment of antitrust damages is not designed to promote optimal deterrence, this example shows that an explicit policy of decoupling antitrust damages would not be as radical a departure from current practice as might be thought.

Before decoupling can be recommended to policy makers, there are several additional issues that need to be considered. Since these issues have not yet been analyzed in a systematic way, I will only list some of the questions that remain to be 
answered: [13]

-How should a system of decoupling deal with outof-court settlements? For example, if at trial the plaintiff would receive less than what the defendant pays, should the settlement be "taxed" by the same amount? By the same percentage? What if the court is unable to monitor the settlement? Will out-of-court settlements tend to subvert or enhance the desirable effects on deterrence of the decoupling approach?

--If at trial the plaintiff would receive more than what the defendant pays, why won't the parties "fabricate" an offense in order to obtain the implicit governmental subsidy? How should a system of decoupling respond to this possibility? Can fabricated offenses be adequately deterred simply by the threat of penalties for such behavior?

- What will be the impact of a system of decoupling on the price of the product sold by the defendant? For example, if the plaintiffs are purchasers of the defendant's product and if they would receive less at trial than what the defendant pays, won't their demand for the product--and consequently the price--be lower than what it would be if they were to receive exactly what the defendant pays? How will the price be affected if the plaintiffs are competitors of the defendant? suppliers to the defendant? Dealers of the defendant? Are the price changes induced by a 
system of decoupling desirable?

If a system of decoupling can deal satisfactorily with the issues raised by these questions, then decoupling may be superior to detrebling not only in theory, but also in practice. 


\section{Notes}

[*] Stanford University and National Bureau of Economic Research. The preparation of this comment was supported by a grant from the Center for Economic Policy Research at stanford. I wish to thank Daniel Rubinfeld and steven Shavell for helpful suggestions in response to an earlier draft.

[1] See, for example, Garvey (1984) and Easterbrook (1985).

[2] Of course, this is also a feature of the present system of treble damages, as well as of proposals to increase the damage multiplier. As will be seen, the principal points of this comment apply regardless of the level of the damage multiplier. My focus is on detrebling because most recent proposals have been to reduce the multiplier.

[3] See Schwartz (1980, pp. 1092-96) and Salop and white (1985, pp. 52 \& 70). See also schwartz (1981, pp. 10-15). Warren Schwartz based his recommendation for decoupling antitrust damages on arguments developed by William Landes and Richard Posner in a paper on the private enforcement of law. See Landes and Posner (1975). See also note 6 below.

[4] See Becker (1968).

[5] The logical implication of this argument is that the fine should equal a firm's net worth. This extreme implication of Becker's theory is not essential to my analysis of detrebling and decoupling.

[6] See Becker and stigler (1974, pp. 13-16). They did, however, raise the possibility at the end of their discussion that private enforcement might not be optimal and that a tax on 
private enforcers might be desirable.

[7] See Landes and Posner (1975).

[8] See Polinsky (1980).

[9] The analogy between competitive private enforcement and private damage actions in antitrust law is not perfect. In the former context, anyone can become an enforcer, whereas in the latter context, only the antitrust victim can, at least nominally, do the enforcing. Moreover, in the antitrust context, the victim must share the award with his lawyer. However, these differences do not seem essential, especially when one considers the entrepreneurial role played by plaintiff antitrust lawyers.

[10] I am, of course, ignoring other means by which enforcement could be reduced, such as changing the allocation of legal costs or changing other procedural or substantive rules. These considerations are beyond the scope of this comment.

[11] If the damage multiplier is so high that it is not possible to raise the amount paid by the defendant, then a slightly different argument would have to be used. However, the conclusion would be the same.

[12] A more precise version of this point is as follows. If, under the damage multiplier approach, private enforcers would overenforce when the damage multiplier is such that the defendant is paying as much as possible, then it is desirable under the decoupling approach for the plaintiff to receive less than what the defendant pays. (An analogous statement could be made in the next paragraph.)

[13] Many of the questions listed below have been answered 
either in the context of general discussions of private versus public enforcement or in the context of specific discussions of private antitrust enforcement (in which the plaintiff receives what the defendant pays). Whether, or to what extent, the answers apply to a system of decoupling is currently unclear. 


\section{$\underline{\text { References }}$}

Becker, Gary S., "Crime and Punishment: An Economic Approach," Journal of Political Economy, Vol. 76, No. 2 (March-April 1968), pp. 169-217.

Becker, Gary S., and George J. Stigler, "Law Enforcement, Malfeasance, and Compensation of Enforcers," Journal of Legal Studies, Vol. 3, No. 1 (January 1974), pp. 1-18.

Easterbrook, Frank H., "Detrebling Antitrust Damages," Journal of Law and Economics, Vol. 28, No. 2 (May 1985), pp. 445-67. Garvey, George E., "Study of the Antitrust Treble Damage Remedy," Report prepared for the Committee on the Judiciary, U.S. House of Representatives, Ninety-Eighth Congress, Second Session, February 1984.

Landes, William M., and Richard A. Posner, "The Private Enforcement of Law," Journal of Legal studies, Vol. 4, No. 1 (January 1975), pp. 1-46.

Polinsky, A. Mitchell, "Private versus Public Enforcement of Fines," Journal of Legal Studies, Vol. 9, No. 1 (January 1980), pp. 105-27.

Salop, Steven C., and Lawrence J. White, "Private Antitrust Litigation: An Introduction and Framework, "Paper prepared for the Georgetown Conference on Private Antitrust

Litigation, Airlie House, Virginia, November 8-9, 1985. Schwartz, Warren F., "An Overview of the Economics of Antitrust Enforcement," Georgetown Law Journal, Vol. 68, No. 5 (June 1980), pp. 1075-1102.

Schwartz, Warren F., Private Enforcement of the Antitrust Laws: 
An Economic Critique (Washington D.C.: American Enterprise Institute, 1981). 